\title{
FUNCSI DAN PERANAN PEMIMPIN INFORMAL MASYARAKAT KAMPUNG URUG DI KABUPATEN BOGOR JAWA BARAT
}

\author{
Oleh Tjetjep Rosmana
}

Balai Pelestarian Sejarah dan Nilai Tradisional Bandung Jln. Cinambo No. 136 Ujungberung Bandung

Naskah diterima:28 Desember 2010

Naskah disetujui:22 Februari 2011

\section{Abstrak}

Pemimpin informal dalam suatu kampung adat sangat berperan penting dalam kehidupan sehari-hari, oleh sebab itu eksistensinya tidak dapat dihilangkan. Ia tumbuh dan berkembang serta muncul dari masyarakat, oleh masyarakat, dan untuk masyarakatnya. Oleh karena itu penulis sangat tertarik untuk mengadakan penelitian tentang Kajian mengenai Fungsi dan Peranan Pemimpin Informal pada Masyarakat Kampung Urug di Kabupaten Bogor. Dengan tujuan untuk mengetahui bagaimana, mengapa dan dalam hal apa saja pemimpin adat di kampung adat tersebut berperan. Dalam penelitian ini digunakan metode deskriptif. Metode ini digunakan untuk memperoleh data seluas-luasnya di lapangan dalam rangka mempelajari kondisi masyarakat yang sedang diteliti. Kegiatan yang dilakukan adalah mencari dan mengumpulkan data mengenai peranan pemimpin adat dalam kehiclupan masyarakat. Data dianalisis secara kualitatif dan diharapkan dapat menggambarkan mengenai peranan pemimpin adat.

Kata kunci: fungsi peranan, pemimpin informal.

\section{Abstract}

Informal leaders play an important role in daily life of a kampung adat. Therefore, his existence can not be eliminated. This kind of leaders grow and develop within, by, and for his community. The author is interested in studying the role and function of an informal leader in Kampung Urug in Kabupaten Bogor, in order to know to what extent is his function and role in the community. The author has conducted a descriptive method, the one that is used to get data as vast as possible during fieldwork to study the community in question and collecting information concerning the role of the adat leader in the life of the society. Data were analysed qualitatively and hopefully they can describe the role of the adat leader.

Keywords: function role, informal leader. 


\section{A. PENDAHULUAN}

Manusia sebagai makhluk sosial tidak pernah mampu untuk hidup seorang diri, di mana atau dalam keadaan apapun manusia cenderung untuk hidup berkelompok. Pengelompokan sosial itu antara lain dilandasi oleh adanya persamaan kepentingan antarsesama anggota kelompoknya. Untuk mewujudkan kepentingan bersama itu, manusia mengorganisir dirinya ke dalam dengan menciptakan seperangkat peraturan dan sebagai pengendalian sosial yang diperlukan seorang pemimpin.

Pemimpin berperan untuk menjalankan, mengatur kehidupan masyarakat. Dengan mengandalkan kemampuan, seorang pemimpin dituntut mampu menjalankan kepemimpinan (leadership) untuk mempengaruhi orang lain agar berbuat sesuatu tanpa paksaan.

Pemimpin informal diakui oleh masyarakat karena dianggap sebagai orang terbaik di kalangan masyarakat karena memiliki kemampuan untuk menjaga amanah serta memecahkan berbagai masalah yang dihadapi masyarakat. Ia menjadi tauladan dan tempat penyampaian keluh kesah. Selain itu, tidak jarang pula tokoh ini dapat memberikan motivasi dan semangat kerja bagi masyarakatnya. Sehubungan dengan itu, kehadiran pemimpin informal mutlak diperlukan. Misalnya untuk memotivasi masyarakat agar mau mendukung dan melaksanakan program pemerintah, seperti program kependudukan (KB), kesehatan, pendidikan, pembangunan, kebersihan, dan keamanan.

Pemimpin informal dianggap berhasil mendekati masyarakat karena kedekatannya, keluwesannya, dan atau kharismanya. Koentjaraningrat (1992: 199) memberi gambaran tentang kekuasaan tradisional, yaitu kekuasaan tradisional mempunyai komponenkomponen kekuasaan serta sifat-sifat yang menjadi syarat bagi seorang pemimpin. Komponen kekuasaan itu adalah kewibawaan, kharismatik, dan kekuasaan dalam arti khusus. Pemimpin informal seperti ulama (kiai) dan ketua adat sangat esensial dalam kehidupan sehari-hari, karena kelompok ini dapat menjawab tantangan dan kemajuan zaman.

Tidak dapat dipungkiri sejarah telah mencatat bahwa kepemimpinan di Nusantara mengalami beberapa dekade, yaitu kepemimpinan pada masa kerajaan, masa kolonial, dan setelah penyebaran agama Islam. Pada masa kerajaan yang selanjutnya kekuasaan berada di bawah pemerintahan penjajahan (Belanda, Jepang, dan Portugis), timbul kefakuman kharisma pemimpin di masyarakat, karena waktu itu raja-raja hanya sebagai abdi penjajah. Masyarakat beralih ke kiai karena dapat membantu menyelesaikan masalah dan membela masyarakat dari tindasan penjajah. Tidak sedikit andil para ulama dalam menjaga dan mempertahankan tanah air yang sekaligus mengusir kolonialisme, sehingga membawa masyarakat ke masa kemerdekaan.

Kampung Urug merupakan salah satu kampung adat di Jawa Barat. Masyarakat patuh kepada ketua adat karena ketua adat sebagai pemimpin informal di masyarakat berperan penting untuk mengatur kehidupan masyarakat, serta mempertahankan nilai-nilai luhur budaya mereka.

Sehubungan dengan hal tersebut di atas, yang menjadi pokok masalah dalam penelitian ini adalah:

1. Bagaimana upaya pemimpin informal dalam mewujudkan fungsi dan peranannya dalam kehidupan 
masyarakat berdasarkan aturan adat yang telah disepakati bersama?

2. Dalam hal apa saja pemimpin informal berperan dalam kehidupan masyarakat?

3. Adakah kesinambungan dengan fungsi dan peranan pemimpin formal?

\section{B. HASIL DAN BAHASAN}

\section{Kampung Urug}

Kampung Urug secara administratif termasuk ke dalam wilayah Desa Kiarapandak, Kecamatan Sukajaya, Kabupaten Bogor. Masyarakat Kampung Urug di bawah kendali dua sistem kepemimpinan, yakni pemimpin informal yang dalam hal ini disebut ketua adat atau olot, dan pemimpin formal seperti ketua rukun tetangga, ketua rukun warga, kepala desa/lurah, dan camat. Pemimpin informal di Kampung Urug adalah pemimpin yang sifatnya lokal karena tumbuh dan berkembangnya atas clasar kebutuhan masyarakat setempat. Sebagai pemimpin informal di sana adalah sesepuh Kampung Urug yang dipanggil dengan sebutan olot atau abah.

Dalam perkembangannya Kampung Urug dibagi menjadi tiga wilayah, yaitu Urug Tonggoh, Urug Tengah dan Urug Lebak yang masing-masing dipimpin oleh seorang olot. Menurut keterangan, pembagian wilayah ini bermula setelah olot Sajiah meninggal kemudian digantikan oleh putranya yang bernama Adang, dan kemungkinan karena olot Adang masih muda, saudara-saudara olot Sajiah melepaskan diri dan masingmasing memimpin Urug Tengah dan Urug Tonggoh. Urug Lebak (Kampung Urug asli) saat ini dipimpin oleh anaknya olot Adang, yaitu olot Ukat.
Kedudukan olot atau ketua adat beriaku secara turun temurun. Keberadaan olot sangat dihormati dan disegani masyarakatnya karena mereka percaya olot sebagai orang yang telah menerima petunjuk gaib (wangsit) karuhun Urug untuk menjadi sesepuh.

Ada tiga orang olot di Kampung Urug sebagai pemimpin informal yang mengendalikan keberadaan kampung adat ini. Pertama, olot Rajasa atau dipanggil olot Koyod yang memimpin Kampung Urug Tonggoh. Ia selain menjalankan petunjuk adat dalam hal tata cara menanam padi yang secara turun temurun, ia pun mempertahankan adat istiadat Urug lainnya. Olot Koyod berperan pula dalam hal juru dongeng atau "pencerita" sejarah Kampung Urug seperti tentang silsilah, riwayat yang berhubungan dengan nilai-nilai tradisional Kampung Urug atau cerita yang mengaitkan raja-raja Pajajaran dengan Kampung Urug. Kedua, olct Amat atau disebut juga olot Tengah yang mewakili Kampung Urug Tengah, bertugas mengatur masyarakat, pengerahan massa dan memberikan petunjuk bagi kesepakatan adat yang sedang dijalankan. Ketiga, olot Ukat atau disebut juga Kokolot Lebak, yang mewakili Kampung Urug Lebak yang mempunyai tugas mengendalikan dan mempertahankan adat istiadat yang sudah turun temurun, seperti upacara adat, serta memimpin kegiatan-kegiatan lainnya yang dianggap sakral.

Olot Ukat sebagai olot Kampung Urug Lebak merupakan salah satu olot Kampung Urug yang dianggap figur bagi olot-olot lainnya. Ia pun merupakan olot bagi keseluruhan masyarakat Kampung Urug. Hal ini dapat dimengerti karena Kampung Urug Lebak merupakan cikal bakal Kampung Urug secara keseiuruhar. 


\section{Olot Ukat merupakan keturunan} ke- 8 dari turunan terdahulunya, yakni mulai dari olot Ijan sebagai pendiri Kampung Urug. Adapun olot di Kampung Urug dimulai dari olot Ijan sampai olot Ukat urutannya adalah olot Ijan, olot Ikem, olot Jariah, olot Surya, olot Sapri, olot Rukman, olot Adang dan olot Ukat.

Konon olot Ukat semasa mudanya dihabiskan di luar Kampung Urug, namun sewaktu ada pergantian olot Adang dan berdasarkan wangsit, jadilah ia orang yang dituakan (Ki Kolot) di Kampung Urug.

Kedudukan olot atau ketua adat berlaku secara turun temurun. Seorang olot memimpin Kampung Urug seumur hidup. Apabila telah meninggal, baru kemudian dipilih penggantinya. Sudah tentu kriteria yang pasti adalah bahwa dia harus berasal dari keturunan olot-olot sebelumnya.

Tanda-tanda calon seorang olot berpeluang besar menjaci olot bila diilhat dari banyaknya tamu yang datang kepadanya. Bila semakin banyak tamu yang datang kepadanya, warga masyarakat sendiri yakin dia memiliki kematih-an atau keampuhan (kemanjuran). Dia dipandang mampu menjembatani keinginan para tamu agar terkabul. Konon ke-matih-an itu datang dari karuhun atau leluhur, dan dengan demikian orang yang memiliki ke-matihl-an dianggap mendapat dukungan dari kat whin.

Kebcradaan olot sangat dihormati dan cisegani masyarakatnya karena mereka percaya olot sebagai orang yang telah menerima peturjuk gaib (wangsit) karuhun Kampurg Urug untuk menjadi sesepuh.

Peranan olot masih bersifat informal, setiap nasihat, saran dan pendapatnya dapat mengendalikan perilaku warga Kampung Urug. Hal ini tergambar dari sikap penduduk, mereka menanyakan nasibnya kepada olot sebelum melakukan sesuatu pekerjaan. Hal tersebut ditempuh untuk menghindari terjadinya malapetaka yang datang dari alam gaib, sebab mereka menganggap malapetaka itu sebagai akibat keteledoran terhadap karuhun-nya atau adanya gangguan dari makhluk jahat, dan untuk mencegahnya olot-lah yang lebih tahu. Ia dianggap sebagai orang yang mampu berhubungan dengan roh halus (alam gaib).

Seorang olot di Kampung Urug menjadi simbol masyarakat yang mas: $h$ cukup teguh mempertahankan tradisi dalam berbagai aspek kehidupan, seperti di seputar aktivitas pertanian, religi, ekonomi, atau berkaitan dengan masalahmasalah dalam kehidupan sehari-harinya. Dia menjadi tempat bertanya para warganya, bahkan masyarakat dari kampung lainnya yang menginduk pada tradisi Kampung Urug. Dia pun menjauii pemimpin dalam setiap acara adat, juga menjadi pengendaii dalam mempertahankan kelangsungan tradisi leluhurnya.

Pemukiman di Kampung Urug khususnya Urug Lebak tersusun sedemikian rupa berbentuk formasi mengelompok dengan tiga titik sentral yaitu Gedong Gede, Gedong Luhur, dan Gedong Alit. Gedong Gede disebut juga Sanghyang Tunggal merupakan bangunan keramat yang khusus diciami oleh olot sebagai ketua adat. Gedong Luhur adalah bangunan kosong berukuran $4 \times 4$ meter dengan tinggi kolong bangunan 4 meter dari atas tanah. Karena kolong bangunan tersebut tinggi, maka bangunan ini disebut Gedong Luhur. masyarakat meyakini bahwa tempat itu berfungsi sebagai tempat 
paniisan karuhun 'peristirahatan leluhur'. Gedong Alit berupa cungkup yang di bagian bawahnya berisi makam karuhun.

faktor lain, seperti di antaranya dorongan atau peranan pemimpin. Peranan seorang pemimpin sangat menentukan kehidupan suatu masyarakat. Peran pemimpin dalam kehidupan masyarakat tidak sama

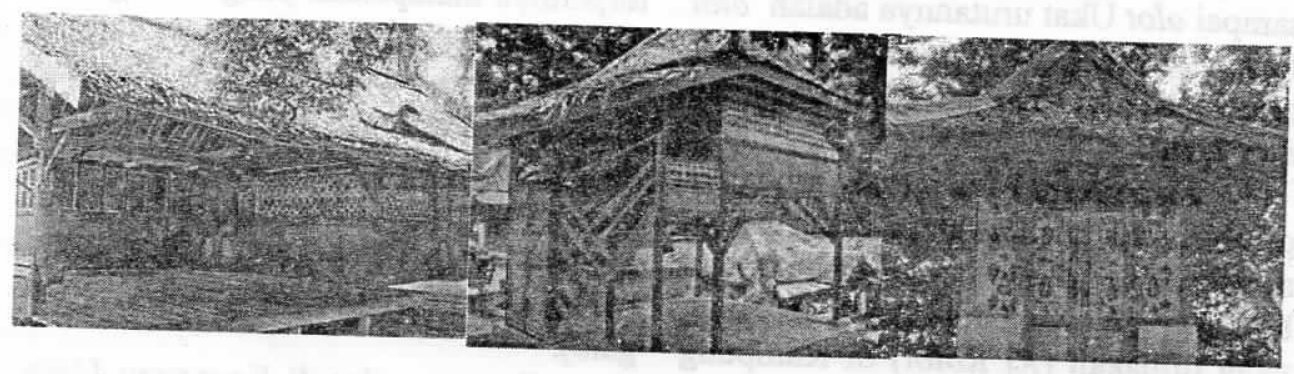

(dari Kiri) Gedong Alit, Gedong Gede, Gedong Luhur Sumber: data penelitian tahun 2009

Ketiga tempat tersebut sangat disucikan dan dianggap sangat tinggi nilainya sakralnya, serta bangunan tersebut dianggap sebagai titik sentralnya pola pemukiman mayarakat Kampung Urug. Semua ini menandakan sistem kemasyarakatan yang berorientasi kepada karuhun sebagai penghuni alam gaib yang mengendalikan kehidupan mereka di dunia ini.

\section{Fungsi dan Peranan Pemimpin Informal}

Manusia sebagai makhluk sosial tidak dapat hidup sendirian. Ia membutuhkan kehadiran orang lain. Oleh sebab itu, ia harus selalu berinteraksi baik di dalam lingkungan keluarga ataupun masyarakat.

Dalam kenyataan sehari-hari, hubungan di antara warga suatu masyarakat tidak selalu dalam kondisi yang optimal, artinya hubungan yang terjalin hanyalah sebatas saling mengenal, tidak lebih dari itu. Erat tidaknya hubungan antar warga suatu masyarakat ini, selain tumbuh dari masyarakatnya dapat juga karena dorongan atau peranan dengan kepemimpinan dalam suatu lembaga.

Soerjono Søekanto mengemukakan: "Suatu perbedaan yang mencolok antarkepemimpinan yang resmi (formal leadership) dengan yang tidak resmi (informal leadership) adalah bahwa kepemimpinan yang resmi di dalam pelaksanaannya selalu harus berada di atas landasan-landasan atau peraturanperaturan resmi. Dengan demikian, daya cakupnya lebih luas. Kepemimpinan tidak resmi, mempunyai ruang lingkup tanpa batas-batas resmi, karena kepemimpinan demikian didasarkan atas pengakuan dan kepercayaan masyarakat" (1990 : 319).

Sebagai tolok ukur berhasil atau tidaknya seorang pemimpin informal salah satunya bergantung pada tujuan dan hasil pelaksanaan kepemimpinannya tersebut, apakah menguntungkan atau merugikan masyarakat. Seorang pemimpin harus memiliki beberapa kemampuan atau kelebihan yang diakui oleh masyarakatnya. Unsur-unsur penting yang harus dimiliki oleh seorang pemimpin diantaranya, harus memiliki idealisme yang kuat, berkemampuan, dan 
mampu mengayomi masyarakatnya. Kepemimpinan informal adalah kepemimpinan yang ditentukan oleh ketentuan adat serta atas pengakuan masyarakat akan kemampuannya untuk menjalankan kepemimpinannya. Dengan adanya suatu pengakuan tersebut diharapkan dapat menciptakan "angin segar" bagi masyarakat untuk meraih kehidupan yang lebih baik serta sesuai aturan yang berlaku pada masyarakat itu.

Dalam masyarakat adat umumnya memiliki seorang pemimpin informal yang peranannya lebih dominan bila kepemimpinan secara adat. Orang yang dianggap sebagai pemimpin adat adalah seorang sesepuh yang biasa disebut $\mathrm{Abah}$ atau olot. Olot sebagai orang yang dituakan, tentu perkataannya sangat dipatuhi oleh masyarakat. Dalam menjalankan tugasnya, olot dibantu oleh lebe dan punduh (tua kampung). Lebe atau ustadz membantu dalam bidang keagamaan, sedangkan punduh membantu tugas sebagai penghubung, penggerak antara sesepuh dengan masyarakat yang biasanya dipilih masyarakat secara garis keturunan.

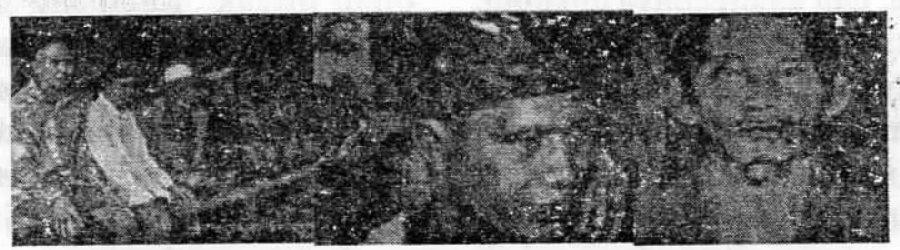

(dari kiri) Tokoh masyarakat, Olot Ukat, dan Olot Adang (alm.) Sumber : Data penelitian tahun 2009

Cibandingkan dengan pemimpin formal, seperti rukun tetangga dan rukun warga, yang terkait langsung dengan sistem pemerintahan dalam mengisi pembangunan dan pengembangan daerahnya. Peran pemimpin informal cenderung mengatur dan mengendalikan kehidupan masyarakat yang sesuai dengan ketentuan yang berlaku.

Pemimpin formal dan informal tadi cukup seirama dalam mengatur roda kehidupan masyarakat Kampung Urug. Keduanya memiliki tugas dan tanggung jawab yang berbeda, namun tetap saling mendukung satu sama lainnya. Koordinasi merupakan kunci sukses keduanya dalam mengatur dan mengendalikan kehidupan masyarakat Kampung Urug. Kampung Urug sebagai salah satu kampung adat memiliki satu struktur kepemimpinan. secara informal dalam arti suatu
Xuncen berperan memberikan petunjuk dalam bidang pemerintahan maupun kemasyarakatan. Peranan kuncen lainnya yang dominan terlihat dalam kehidupan sehari-hari dari setiap nasihat, saran, dan pendapatnya yang selalu mengendalikan perilaku masyarakat. Oleh karena itu, masyarakat sangat menghormati dan mematuhi apa yang digariskan nenek moyangnya melalui kuncen.

Kedua bentuk kepemimpinan yang ada di masyarakat Kampung Urug dalam kesehariannya menunjukkan kerja sama yang baik dalam mengatur keharmonisan, baik antara masyarakat di wilayah Kampung Urug maupun di luar wilayah, seperti dengan masyarakat Kiarapandak lainnya. Dengan adanya sikap saling pengertian dan menghormati antarkedua sistem kepemimpinan maka keduanya 
dapat bekerjasama dalam melestarikan nilai-nilai luhur yang telah lama mereka pegang sebagai pedoman dalam kehidupan.

Dalam kehidupan sehari-hari, masyarakat Kampung Urug selalu taat pada aturan-aturan pemerintah. Walaupun demikian, dalam kehidupan religi, masyarakat selalu taat kepada petunjuk olot sebagai sesepuh di Kampung Urug. Peran olot sebagai pemimpin informal, di mata warganya merupakan figur kharismatik yang begitu dihormati dan dicintai. Nasihatnya selalu didengar, perintahnya senantiasa dilaksanakan, dan larangannya dipatuhi. Pendapatnya selalu mengendalikan setiap perilaku warganya. Selain itu, olot juga menjadi tempat mencurahkan segala permasalahan yang dihadapi warga, baik dari dalam maupun dari luar Kampung Urug. Secara umum, sikap olot menjadi tauladan bagi warga masyarakatnya. Dalam menjalankan tugasnya, olot dibantu oleh amil yang khusus menangani dan mengurus bidang keagamaan, seperti pernikahan, atau kematian. Proses pemilihan olot tidak ditentukan oleh masyarakat, tetapi melalui wangsit. Oleh karena itu, calon olot harus keturunan langsung dari olot sebelumnya, serta memiliki wawasan atau pengetahuan yang berkaitan dengan tradisi karuhun. Keberadaan olot yang menjadi ketua adat Kampung Urug juga memberi warna tersendiri pada sistem pemerintahan desa. Roda pemerintahnan berjalan tidak hanya bertumpu pada hal-hal formal, karena nuansa lokal pun memberi kontribusi di dalamnya. Kepemimpinan lokal, dalam hal ini diwakili olot, tidak dapat dipandang sebelah mata. Hal ini terlihat dari begitu besar peranan dan pengaruh olot di lingkungan masyarakat Kampung Urug yang tentunya berpengaruh pula terhadap sistem pemerintahan desa.

Peran dan pengaruh olot terhadap sistem pemerintahan desa cukup signifikan. Aparat pemerintah desa atau yang lebih tinggi lagi, tidak hanya berkoordinasi dengan ketua rukun warga atau ketua rukun tetangga, mclainkan juga dengan olot. Jalinan koordinasi ini tidak hanya sekadar urusan adat istiadat setempat saja, melainkan juga melebar ke urusan administrasi dan program pemerintah yang akan diimplementasikan ke dalam lingkungan masyarakat Kampung Urug. Dapat dikatakan bahwa "pintu masuk" Kampung Urug adalah rumah olot. Adapun "kunci pintunya" adalah olot, yang mensahkan atau tidaknya hal baru masuk dan menjadi bagian dari kehidupan masyarakat Kampung Urug. Olot juga kerap mendapat undangan resmi dari pemerintah untuk berbagai kepentingan, baik di tingkat desa, kecamatan maupun tingkat pusat. Hal ini menandakan peranan olot yang cukup diperhitungkan.

\section{a. Fungsi dan Peranan Pemimpin Informal dalam Bidang Kemasyarakatan}

Masyarakat Kampung Urug masih memegang teguh adat istiadat yang mengatur tingkah laku dan dipakai sebagai pedoman untuk bertindak bagi masyarakat. Adat istiadat dianggap sebagai warisan nenek moyang yang berisi aturan-aturan di semua bidang kehidupan yang harus dipatuhi. Sebagai seorang pemimpin adat, olot Ukat memiliki peran yang sangat besar dalam mengatur dan mempertahankan nilai-nilai yang dianut oleh masyarakatnya.

Dalam melaksanakan kehidupan sehari-hari, masyarakat Kampung Urug 
berpegang pada penuturannya terutama pada hal-hal yang dilarang atau tabu dan perlu ditaati. Tabu dan anjuran yang perlu ditaati masyarakat Kampung Urug salah satunya adalah dalam bidang pertanian. Dalam tabu atau anjuran tersebut, pantang bagi masyarakat Kampung Urug untuk mengurus pertanian pada hari Senin, karena konon pada hari itu Dewi Sri mendapat haid pertama kali. Sedangkan pada hari Jumat, darah menstruasinya disiram dengan air dan jatuh ke bumi. Hari Jumat merupakan pantangan bagi petani Urug untuk pergi ke ladang atau sawain. Hingga saat ini sebagian besar masyarakat Kampung Urug masih menjaga tradisi warisan para karuhun. Pantangan tersebut berlaku pula pada perlakuan terhadap peralatan rumah tangga tradisional seperti pada tungku "haw:l". Tungku adalah tempat memasak yang paiing penting dalam rumah tangga. Masyarkkat Kampung Urug terutama bagi perempuan yang sedang hamil pantang atau tidak boleh menginjakkan kakinya disekitar tungku ' hawu'. Jika dilanggar maka bayi yang dilahirkan akan timbul bercak-bercak merah dan apabila diinjak oleh seorang gadis maka akan susah mendapat jodoh.

Dalam kaitannya dengan kehidupan sehari-hari, sesepuh adat atau olot mempunyai peranan yang cukup penting, yaitu memberi petuah dan menjelaskan tentang riwayat berdirinya Kampung Urug. Pemberian petuah paling sering dilakukan pada saat berkumpul bersama di Gedong Gede yakni petuain atau nasihat mengenai adat atau tata cara yang telah dilakukan para leluhur. Petuah tersebut harus dipatuhi oleh warga terutama kaum muda yang dianggap masih awam dan kurang mendalami aturan-aturan adat istiadat yang berlaks. Musyawarah atau pertemuan, biasanya terjadi saat seluruh warga hadir misalnya dalam pelaksanaan upacara adat. Selain itu, olot sebagai sesepuh adat sering mengaitkan hal-hal yang sedang dimusyawarahkan dengan aturan adat di Kampung Urug.

Pada aspek kemasyarakatan, sesepuh aciat pun memegang peranan yang sangat-penting dan menonjol. $\mathrm{Hal}$ ini terlihat dari tugas-tugas yang diembannya, di antaranya bertugas mencarikan dan menentukan hari baik warga yang akian melangsungkan acara pernikahan, kitanan, atau bertanya kapan mulai bertani, dan sebagainya. $K i$ Kolot pun, dalam hal ini olot Ukat, selain sebagai tempat bertanya bagi masyarakat setempat ataupun warga yang datang dari luar Kampung. Urug, juga dianggap sebagai tolsoh masyarakat yang sangat disegani dan dihormati. Hal ini tampak dalam persiapan upacara pernikahan dan upacara adat lainnya, Olot Ukat selalu diharapkan hadir untuk memberi doa restu. Kehadirannya sangat diharapkan warga karena dianggap memberi berkah dan doa restu. Ketua adat juga berperan sebagai pemimpin dalam kegiatan rapat atau musyawarah yang diadakan warga. Di Kampung Urug sering diadakan musyawarah yang intinya membahas mengenai kegiatan sosial seperti kerja bakti masalah kebersihan lingkungan, keamanan, kegotongroyongan, dan kegiatan warga lainnya. Dalam pertemuan tersebut biasanya dihadiri oleh tokoh masyarakat lainnya, seperti ketua rukun tetangga/rukun warga, para tokoh masyarakat maupun para pemuda dan pemudi. Di dalam pertemuan ini tidak kalah pentingnya dihadiri pula oleh ketua adat yang bertindak sebagai sesepuh yang memberi petuah atau nasihat serta memimpin rapat agar berjalan lancar. Walaupun keputusan akhir memang pada 
musyawarah juga, namun arahan dan petunjuk dari olot sebagai sesepuh sangatlah diperlukan.

Komunikasi di lingkungan masyarakat Kampung Urug berlangsung dengan mempergunakan bahasa Sunda. Dalam perihal hubungan antarwarga tidak tampak peranan pemimpin informal. Hubungan antarwarga terjalin secara akrab. Di antara warga Kampung Urug seyogyanya telah saling mengenal. Walaupun demikian, jalinan hubungan yang sifatnya lebih dari itu, yakni yang sifatnya lebih akrab, pada umumnya hanya terbina dengan mereka yang berada di lingkungan terdekatnya seperti tetangga sebelah atau dengan mereka yang memiliki kepentingan yang sama, misalny kegiatan atau perkumpulan.

Kegiatan yang bersifat sosial yang ada di Kampung Urug seperti sistem keamanan lingkungan (Siskamling), pendidikan kesejahteraan keluarga (PKK), dan Organisasi Pemuda, mendapat perhatian khusus dari sesepuh adat selaku pemimpin informal. Ia selalu memberi semangat dan mengawasi jangan sampai melanggar aturan adat.

Siskamling merupakan organisasi keamanan lingkungan yang sangat diperlukan dan diperhatikan oleh seluruh masyarakat Kampung Urug. Hal ini mengingat kondisi wilayah Kampung Urug, baik itu menyangkut rumah maupun kondisi lingkungan alam sekitar Kampung Urug yang relatif rawan longsor. Seluruh masyarakat menyadari akan hal itu karena menyangkut keselamatan jiwa mereka. Hal lain yang sangat mengkhawatirkan adalah masalah kebakaran karena bentuk rumah-rumah mereka sebagian masih banyak yang terbuat dari kayu, bilik dan ijuk yang sangat mudah sekali terbakar. Setiap malam mereka berkeliling memeriksa setiap rumah, barangkali ada penghuni rumah yang lupa memadamkan api tungkunya yang mengakibatkan terjadinya kebakaran. Dengan digalakkannya Siskamling minimal dapat menjaga sekaligus memberitahu penduduk apabila terjadi hal-hal yang tidak diinginkan.

Organisasi PKK bertugas membina ibu-ibu untuk mengatasi masalah kesejahteraan keluarga melalui berbagai kegiatan, baik yang menyangkut tentang kesehatan, keterampilan, maupun kegiatan sosial lainnya. Dalam kenyataannya, organisasi ini di Kampung Urug tidak begitu berhasil karena selain ibu-ibunya disibukkan sebagai icu rumah tangga juga ditambah dengen kegiatan membantu pekerjaan suami dalam mengurus lahan pertanian atau ladang. Selain itu, letak Kampung Urug berada di lembah yang cukup jauh dan sulit dijangkau oleh penggerak PKK dari unsur-unsur desa maupun keiurahan. Hasilnya, ke-10 program PKK tidak dapat dilaksanakan dengan sepenuhnya. Namun, program KB di Kampung Urug cukup berhasil. Ibu-ibu yang masih berusia produktif telah menjadi anggota Keluarga Berencana KB. Alat-alat kontrasepsi yang dipakai adalah IUD, pil, MOP dan Spiral. Sebelum pemerintah melancarkan program $\mathrm{KB}$ di daerah ini, masyarakat Kampung Urug telah memiliki pengetahuan untuk menjarangkan kelahiran dengan cara mempergunakan ramuan tradisional.

Di dalam aspek kegiatan sosial kiranya nilai kegotongroyongan masyarakat di Kampung Urug masih tertanam dengan baik dan utuh. Istilah babantu atau kerja bakti adalah kegotongroyongan yang dikenal oleh masyarakat Kampung Urug. Babantu adalah kegiatan tolong-menolong dalam 
mengerjakan sesuatu pekerjaan, agar yang dikerjakan itu tidak terasa berat.

Di Kampung Urug dikenal dengan istilah grojogan. Artinya kerja bersamasama untuk kepentingan bersama. Biasanya warga Kampung Urug setiap hari Jumat dan Minggu melakukan kerja bakti, di antaranya memperbaiki jalan, membersihkan selokan (irigasi), membersihkan masjid, membuat sarana umum $(\mathrm{MCK})$, dan sebagainya. Membersihkan Gedong Leutik atau tempat makam keramat dilakukan satu tahun dua kali, yaitu setiap satu hari menjelang Idul Fitri dan Idul Adha.

Nilai kegotongroyongan dapat dikatakan masih sangat kuat. Hal ini terbukti sewaktu akan diselenggarakan upacara adat dimana semua masyarakat terutama ibu-ibu, di bawah koordinasi ketua adat, secara bergotong royong ikut menyediakan berbagai kelengkapan upacara.

Peranan sesepuh adat atau olot Kampung Urug dalam aspek kemasyarakatan juga tercermin dalam pelaksanaan upacara adat yakni sebagai pemimpin dalam pelaksanaan upacara adat. Satu hal yang sangat penting dalam kehidupan masyarakat Kampung Urug adalah terjaganya hubungan yang harmonis dengan entitas supranatural. Dalam pandangan mereka, entitas supranatural terdiri atas Tuhan dan leluhurnya. Bagaimana hubungan mereka dengan entitas supranatural tadi, akan terlihat dari gambaran sistem keyakinan yang dimiliki oleh mereka. Sistem keyakinan masyarakat adat tersebut begitu mewarnai hampir semua aspek kehidupan warga masyarakat, baik yang berkenaan dengan aktivitas ekonomi, sosial, adat istiadat, maupun dalam sistem kepemimpinan.
Seluruh warga masyarakat adat Kampung Urug menganut agama Islam. Walauun demikian, mereka masih kukuh pada ajaran-ajaran adat yang menjadi kekayaan spiritual mereka. Kedua keyakinan ini dalam kenyataan hidup sehari-hari berjalan berdampingan, dalam arti bahwa kedua-duanya sama-sama dilaksanakan. Bahkan dalam suatu kegiatan ritual kedua unsur ini sama-sama dijalankan, sehingga kegiatan ritual mereka pun merupakan sinkretisasi dari kedua unsur ini. Sistem keyakinan menjadi konsep sentral yang melahirkan berbagai bentuk aturan adat, sistem pantangan adat atau tabu, dan berbagai bentuk ritual dikemas dan diformulasikan dalam bentuk upacara-upacara tradisional.

Sistem keyakinan masyarakat Kampung Urug terdiri atas kepercayaan yang bersumber dari agama dan kepercayaan warisan dari leluhur mereka. Masuknya zgama Islam ke Kampung Urug sccara otomatis mengubah pola hidup masyarakat setempat, meskipun masih ada sisa sisa "kebiasaan" karuhun yang dipertahankan. Gabungan dari kebiasaan yang sangat baik terlihat dalam upacara Seren Taun/ Pataunan. Ada anggapan "haram" hukumnya mencampurkan padi yang belum dikeluarkan zakatnya ke leuit dengan padi yang lama. Zakatrya pun cukup besar tidak kurang dari $10 \%$ dari hasil taninya. Hasil dari zakat ini nantinya akan digunakan oleh masyarakat Kampung Urug saat terkena krisis ekonomi, seperti yang diungkapkan kokolot Ukat bahwa dengan satu kali panen cukup untuk hidup selama 2 tahun. Padahal jenis padi yang ditanam adalah pare gede yang umurnya $6-8$ bulan dengan hasil panenan tidak lebih dari 3 ton sekali tanamnya. Satu hal yang tidak mungkin bila dihitung dengan matematik 
dan kurang masuk akal bila dikalikan dengan biaya hidup saat ini.

Masyarakat Kampung Urug hidup di lingkungan suatu kampung adat yang secara fisik mereka menempati rumahrumah dengan bentuk dan bahan bangunan yang sama. Namun dalam perkembangannya kini bentuk dan bahan yang digunakan bervariasi. Artinya sebagian masyarakat Kampung Urug ada yang masih menempati rumah-rumah berbentuk panggung, berdinding dan berlantai dari kayu atau bambu serta beratap ijuk banyak pula yang telah membangun atau menempati rumah yang dibangun semi permanen maupun permanen. Rumah yang semi permanen adalah berdinding setengah tembok, dan setengah bilik atau triplek serta beratap genteng, asbes atau seng. Lantainya, ada yang masih tanah atau dipelur dengan semen. Sedangkan rumah yang permanen, berdinding tembok, beratap genteng, bahkan ada yang berlantai keramik. Tidak ketinggalan pula mereka menggunakan alat penerangan listrik. Hal demikian menandakan bahwa telah ada pergeseran pola pikir masyarakat Kampung Urug, tetapi mereka pun tidak mengesampingkan adat istiadat. Menyikapi hal demikian, ketua adat atau olot bertutur bahwa ia memang berkewajiban untuk mengingatkannya, namun permasalahan itu dikembalikan kepada pribadinya masing-masing, karena mereka pun tahu sendiri resikonya.

\section{b. Fungsi dan Peranan Pemimpin Informal dalam Bidang Pendidikan}

Pendidikan dalam lingkup luas mencakup berbagai aspek kehidupan manusia. Tidak saja berkisar dengan murid, siswa, guru, sekolah, kepala sekolah atau lain-lain yang berkaitan dengan

unsur-unsur

bagi terselenggaranya proses belajar mengajar. Pendidikan mencakup pula halhal yang bersifat abstrak yang kadangkadang tidak diajarkan di sekolah formal. Oleh karena itu, wahana pendidikan seorang anak manusia dibagi ke dalam dua bagian besar, yaitu pendidikan formal dan informal.

Pendidikan formal jelas arahnya. Jelas jenjang pendidikannya dan jelas pula materinya. Seseorang yang pernah mengenyam pendidikan formal secikit banyak akan memperoleh selembar tanda kelulusan pendidikannya, baik lulusan sekolah dasar, lulusan sekolah lanjutan tingkat pertama, maupun lulusan pendidikan yang lebih tinggi lagi. Sementara pendidikan informal cenderung tidak menunjukkan tandatanda konkret dalam proses pendidikanzya.

Adakah kelebihan dan kekurangan dari adanya pembagian jalur pendidikan di atas? Pada hakikatnya, kedua pendidikan yang dimaksud saling berkaitan. Artinya, kesinambungan pendidikan seorang anak sangat bergantung pada kedua pendidikan tersebut. Seorang manusia yang sukses di jalur pendidikan formal di atas kertas mungkin akan memperoleh gambaran masa depan yang cerah. Itu artinya tidak akan mendapat kesulitan dalam hal mencari mata pencaharian. Namun berbeda dengan mereka yang tidak mengenyam jalur pendidikan formal, boleh dikatakan mereka dalam bayangan "madesu" masa depan suram. Tampaknya hubungan jalur pendidikan formal dan informal "pas" bila dikatakan sebagai hubungan saling mengisi.

Gambaran sebuah kampung adat secara umum menunjukkan ketertutupan dan ketertinggalan bagi adanya "pendidikan dunia luar". Orang sering 
terjebak dengan bayangannya sendiri yang mengukur kemajuan seseorang dengan ukuran "bajunya" sendiri. Kita harus menyadari perkembangan zaman sama dengan perubahan pola pikir manusia termasuk pula mereka yang berada di sebuah kampung adat. Kita ambil sebagai contoh adalah Kampung Urug yang terletak terpencil jauh dari keramaian. Suatu hal yang wajar bagi sebuah kampung atau pedesaan terintervensi oleh kekuatan yang lebih kuat darinya. Pemimpin kampung atau kepala dusun, atau apa pun sebutannya, tak dapat berbuat apa-apa manaka'a warga yang dipimpinnya mengambil jalan yang berseberangan dengan kemauan dirinya, terutama sekali dalam ha'. urusan duniawi. Dalam urusan kepercayaan atau anutan warganya boleh jadi masih mempunyai wibawa dan kharisma. IJamun dalam halhal di luar itu semua, kadang-kadang warganya tidak berkiblat kepadanya. Cenderung ia berciikari selama tidak menyalahi dan dipandang baik dan berguna, baik untuk dirinya maupun untuk khalayak ramai.

Sehubungan dengan hal itu kedua pendidikan yang dimaksud di atas, yaitu pendidikan formal dan informal di lingkungan penduduk Kampung Urug tidak mengalami kesulitan-kesulitan apa pun. Keduanya berjalan apa adanya. Pendidikan formal, mereka lakukan dengan memasuki berbagai tempat pendidikan seperti sekolah dasar. Sedangkan pendidikan informal mereka peroleh dari hubungan teman atau keluarga. Usaha lainnya yang menyangkut keterampilan (praktek) dilakukan oleh ibu-ibu misalnya cara membuat olahan makanan sering diperoleh dari upaya sendiri (individu) dengan cara melihat atau mencoba tanpa melalui kursus atau sekolah. Demikian pula keterampilan yang diperuntukan bagi remaja dilakukan oleh para remaja. Peranan ketua adat, atau olot dalam hal ini sangat mendukung secara moril maupun materil. Namun keberhasilannya ditentukan oleh pribadinya sendiri.

Dalam hal pendidikan formal, peranan orang tua atau keluarga dominan sekali. Seolah-olah pendidikan formal ini merupakan urusan keluarganya masingmasing yang tidak perlu orang lain mencampuri, termasuk pemimpin informal. Sosok pemimpin informal tidak begitu dominan dalam urusan pendidikan seseorang, kecuali dalam hal yang bersifat khusus seperti keagamaan, atau hal-hal yang menyangkut adat istiadat seperti dalam pelaksanaan sebuah upacara, dan lain sebagainya.

\section{c. Fungsi Peranan Pemimpin Irformal dalam Bidang Azama}

Manusia terdiri atas unsur jasmani dan rohani. Kedua unsur ini tidak saling meniadakan, artinya kedua-duanya memiliki tingkat kepentingan yang sama. Unsur-unsur tersebut dapat tumbuh mulus dan seimbang apabila kebutuhannya senantiasa terpenuhi. Salah satu kebutuhan rohani manusia adalah dengan pemenuhan keagamaan. Dengan demikian, agama merupakan bentuk kebutuhan manusia yang harus terpenuhi.

Manusia tanpa agama akan hidup tidak menentu, tanpa arah dan tujuan. Mengapa demikian? Agama adalah pegangan atau pedoman yang menggerakkan manusia melalui itikad, ucapan dan perbuatan, agar selalu menjadi manusia yang berguna, baik bagi dirinya, keluarga, masyarakat maupun pada bagian yang sangat luas yaitu bangsa dan negara. Dengan agama pula manusia dibekali, diajari, dan diberi pengetahuan bahwa kehidupan itı tidak hanya di dunia, 
ada lagi kehidupan yang abadi, yaitu kehidupan akhirat. Dunia sebagai tempat berjuang untuk mengumpulkan bekal bagi kehidupan yang akan datang. Dampak perilaku keagamaan dapat dikenal dengan mudah, yaitu dengan memperhatikan nilai-nilai yang tampak pada tingkah laku keseharian. Oleh karena itu, seseorang dapat menilai tingkat kesemarakan beragama pada suatu masyarakat dari perilaku pergaulan masyarakatnya, apakah kurang baik, biasa-biasa, atau baik. Seperti yang tampak pada masyarakat Kampung Urug dengan memperhatikan cara berpakaian, cara berbicara, dan kelengkapan sarana peribadatannya. Dari kriteria tersebut membuktikan bahwa masyaral:at setempat termasuk masyarakat yang agamis. Masyarakat yang agamis adalah masyarakat yang secara keseluruhan dalam kehidupannya memiliki kesadaran dan ketaatan kepada agama.

Kampung Urug dapat dikatagorikan sebagai kampung adat yang taat menjalankan ajaran Islam. Pernyataan ini didukung dengan pengakuan yang dilontarkan oleh masyarakat bahwa mereka mengaku beragama Islam, terlepas dari cara-cara mereka beribadah atau mendekatkan dirinya kepada Allah Swt. serta terbukti sering dilakukan kegiatan pengajian. Aktivitas keagamaan sehari-hari diwujudkan dalam kegiatan pengajian, baik anak-anak maupun ibuibu. Pengajian anak-anak berlangsung setiap Magrib dan Subuh, mereka belajar membaca Al-Quran. Pengajian ibu-ibu dilaksanakan setiap hari Jumat, setelah sembahyang Ashar. Selain itu mereka menyelenggarakan kegiatan hari-hari besar Islam seperti Mauludan dan Rajaban. Aktivitas keagamaan tersebut berada di bawah bimbingan pemimpin agama, amil atau ustadz. Pembinaan keagamaan sebenarnya dapat dilakukan sejak anak masih kecil, karena ketika lahir pun dan selama berkembang si anak langsung menerima pelajaran dengan cara mendengar dan melihat perilaku orang tuanya. Pihak orang tua pun sangat dominan dalam mengarahkan putraputrinya agar dapat menjadi anak dan orang yang diharapkan. Orang tua selalu meneladani, juga mengajarkan langsung membaca lafaz-lafaz ayat suci Al-Quran dan memberi nasihat keagamaan. Pembinaan keagamaan anak-anak di Kampung Urug ditempuh dengan jalur informal. Jalur informal dilakukan dengan pembekalan ilmu dan pengetahuan ajaran keagamaan pada saat kegiatan mengaji yang diberikan oleh seorang lebe atau ustadz. Lebe atau ustadz merupakan kaki tangan kuncen atau olot yang diberi tugas sebatas menangani masalah pembinaan keagamaan seperti kebajikan, dan sebagainya. Pembinaan keagamaan ini biasa dilakukan di masjid yang berdiri di tengah-tengah Kampung Urug. Di masjid ini selain digunakan untuk shalat lima waktu (shalat Subuh, Dluhur, Ashar, Magrib, dan Isha) juga dipergunakan untuk shalat Idul Fitri dan Idul Adha.

\section{d. Fungsi dan Peranan Pemimpin Informal dalam Bidang Adat Istiadat}

Kebudayaan pada hakikatnya dimanifestasikan oleh adanya pergaulan dalam arti yang luas. Pergaulan adalah bagian dari rangkaian interaksi sosial. Interaksi ini dikemudikan oleh seperangkat keyakinan yang kita sebut 'pegangan hidup'. Disadari ataupun tidak, secara individual perangkat kepercayaan atau keyakinan itu dimiliki oleh setiap orang.

Bagaimana kita menanggapi sesuatu, memikirkan, memutuskan, dan bertindak terhadapnya, ditentukan oleh 
sifat dan corak perangkat kepercayaan itu. Oleh karena bersifat individual, maka corak pendekatan dalam pelaksanaan interaksi bagi setiap orang berlainan, itu sebabnya orang bisa berbeda-beda pendapat dan tafsir tentang sesuatu masalah yang sama. Kemudian karena sifatnya yang individual dan interaksi setiap orang berlainan, tentunya peranan pemimpin informal dalam hal ini perlu mengatur dan mengarahkan sesuatu yang berlaku dalam tatanan kehidupan seharihari seperti halnya yang ber'aku pada masyarakat Kampung Urug. Perangkat kepercayaan atau keyakinan tidak dengan sendirinya ada, melainkan ia harus dibentuk dan dikembangkan. Manusia berkembang melalui proses pertumbuhan "endapan-endapan" dari pengalaman yang berlangsung semenjak orang masih kecil, bahkan semenjak masih bayi, bahkan sejak janin dalam kandungan. Apalagi masyarakat Kampung Urug berpegang pada ajaran agama Islam. Dalam praktiknya, mereka masih dipengaruhi oleh "endapanendapan" pengalaman yang mereka yakini dan percayai.

Pengalaman-pengalaman itu menjadi milik jiwanya dan diwujudkan melalui proses awal yang kita kenal dengan istilah persepsi. Persepsi inilah yang pada tingkat selanjutnya dan dalam keadaannya yang telah konstan menentukan jenis serta sifat perangkat keyakinan hidup seseorang. Dalam kaitan dengan persepsi ini, orang harus terus menerus diberi dan dikenalkan pada pengalaman-pengalaman yang diendapkannya dalam perangkat kepercayaan atau keyakinan sepanjang hidupnya.

Masyarakat Kampung Urug masih melakukan hal-hal yang bertalian dengan kebiasaan atau adat istiadat yang berlaku sejak dahulu, di antaranya yang bertalian dengan adat istiadat seperti salah satunya terdapat pada ritual upacara yang berhubungan dengan pertanian. Adat istiadat yang erat pertaliannya dengan lingkaran hidup antara lain tentang upacara tradisional. Upacara tradisional yang dimaksud antara lain upacara Sedekah Bumi, Seren Taun, Sedekah Kabuli (Tutup Taun Tanggal Taun), Sedekah Rewah, dan sebagainya..Di sela-sela aktivitas pertanian biasanya diselipi serangkaian tradisi yang menyertai kegiatan, yaitu upacara dalam bertani (menanam padi) meliputi upacara Sedekah Bumi, Salametan Tandur, Salametan Gede Pare, Salametan Panen. Salametan Nganyaran, hingga puncaknya yaitu upacara Seren Taun.

\section{e. Fungsi dan Peraran Pemimpin Informal dalam Bidang Kesanian}

Dalam kebudayaan, kesenian ticak hanya berurusan dengan kebutuhan akan rasa keindahan, tetapi memiliki fungsifungsi sosial, ekonomi, dan ritual. Masyarakat Sunda memiliki kekayaan seni yang cukup beragam, baik jenis vokal maupun seni yang menggunakan waditra atau peralatan (gamelan, gendang, kecapi, dog-dog, alat gesek, suling, goong dan sebagainya), seni tari maupun teatrika. Beberapa jenis kesenian yang terdapat di Kampung Urug antara lain wayang golek, degung, pencaksilat, rebana/tagoni, dan jaipongan. Komunitas adat Urug masih memelihara kesenian tradisional Sunda tersebut. Golongan yang sudah tua mampu membina generasi muda untuk mencintai dan memelihara berbagai kesenian yang ada. Ada beberapa hal yang sangat memungkinkan bagi mereka untuk memelihara kesenian tradisional. Pertama karena sejumlah upacara tradisional di Kampung Urug senantiasa 
Patanjala Vol. 3, No. 1, Maret 2011: 136-153

menyertakan kesenian sebagai bagian syarat acara upacara. Ada acara yang dikhususkan untuk menghibur masyarakat seperti pertujukan wayang golek pada puncak kegiatan upacara Seren Tahun. Bahkan jika ada warga yang cukup berada melaksanakan hajat khitanan, mereka mementaskan wayang golek. Mengingat dirasakan penting kesenian bagi masyarakat, Olot sebagai sesepuh memiliki seperangkat gamelan wayang golek yang disimpan di rumahnya, dan digunakan bila saat ada upacara adat. Selain wayang golek, ada kesenian degung. Kesenian degung biasanya dipertunjukkan bila ada acara resmi, seperti syukuran khitanan atau pernikahan. Sebenarnya di Kampung Urug belum terbentuk perkumpulan degung. Walaupun demikian, apabila masyarakat Kampung Urug menginginkan pertunjukan kesenian degung maka mereka akan mengundang tim kesenian degung dari luar Kampung Urug. Olot sebagai sesepuh Kampung Urug, selalu berupaya untuk memberi dorongan moril kepada generasi muda agar mereka selalu mencintai kesenian tradisional, karena kesenian itu merupakan salah satu segi kehidupan manusia yang tidak dapat dipisahkan dengan segi-segi kehidupan lainnya. Mereka menganggap kesenian sebagai warisan dari nenek moyang yang masih kuat memegang tradisi warisan leluhurnya. Peranan Ketua adat 'olot' dalam bidang kesenian sangat dominan. Walaupun demikian, permasalahan yang dihadapi adalah ketiadaan perlengkapan kesenian yang cukup memadai. Kalau pun ada seperangkat gamelan di Bumi Ageung (rumah olot Ukat) dan di rumah olot Rajasa (abah Koyod) kondisinya sangat mengkhawatirkan. Selain itu mereka mengharapkan adanya pembinaan untuk meningkatkan kemampuan kreativitas dalam kesenian.

\section{f. Fungsi dan Peranan Pemimpin Informal dalam Bidang Pembangunan}

Pembangunan sebenarnya merupakan program perubahan yang direncanakan dan dikehendaki. Setidaknya pembangunan pada umumnya merupakan kehendak masyarakat yang diwujudkan dalam sebuah keputusan yang diambil oleh para pemimpin mereka. Keputusan tersebut disusun dalam suatu perencanaan yang selanjutnya direalisasikan. Pembangunan tersebut mungkin hanya menyangkut satu bidang kehidupan, namun mungkin juga dilakukan secara simultan terhadap berbagai bidang kehidupan yang berkaitan. Bidang pembangunan yang terlihat di Kampung Urug adalah pembangunan fisik yang diperuntukkan bagi kepentingan umum, di antaranya masjid, MCK, dan jalan. Selain digunakan sebagai tempat beribadah, mesjid juga digunakan sebagai pusat kegiatan keagamaan lainnya, seperti Mauludan dan Rajaban. Peran pemimpin informal di bidang pembangunan, khususnya pembangunan masjid pun menjadi indikator yang sangat penting. Oleh karena itu, antara ketua adat dan pengurus masjid harus bekerjasama dengan baik, dalam arti saling memberi saran demi mewujudkan kemajuan dalam bidang keagamaan. Sedangkan pembangunan di bidang pembuatan atau perbaikan MCK ataupun jalan kiranya merupakan sarana yang cukup penting dalam kehidupan masyarakat Kampung Urug. Oleh karena itu, pembangunan kedua sarana tersebut diperoleh dari desa dan sebagian dari swadaya masyarakat. Peran masyarakat dalam pemperbaiki jalan dan MCK 
tidaklah kecil. Dengan dipimpin tokoh masyarakat atau ketua kampung, masyarakat pun berpartisipasi dalam memelihara jalan dan sarana umum lainnya.

\section{PENUTUP}

Dari uraian di atas dapat disimpulkan bahwa masyarakat Kampung Urug memiliki dua sistem kepemimpinan, yakni pemimpin formal dan informal. Pemimpin informal dalam hal ini ketua adat 'olot' peranannya cukup penting dalam berbagai aspek kehidupan masyarakat. Di mata warganya, olot merupakan figur kharismatik yang dihormati, disegani, dicintai dan diteladani, serta segala nasihatnya selalu didengar, perintahnya senantiasa dilaksanakan. Selain itu, olot menjadi tempat mencurahkan segala permasalahan atau keluh kesah yang dihadapi warganya. Keberadaan olot juga memberi warna tersendiri pada sistem pemerintahan desa. Roda pemerintahan berjalan tidak hanya bertumpu pada hal-hal formal, karena nuansa lokal pun memberi kontribusi di dalamnya. Olot sebagai pemimpin lokal, tidak dapat dipandang sebelah mata.

Peranan olot sangat besar dan berpengaruh di lingkungan masyarakat. Hal itu berimplikasi juga terhadap sistem pemerintahan desa. Ketua adat atau olot berperan sebagai pembina masyarakat demi mempertahankan keberlangsungan adat istiadat leluhurnya. Mengingat betapa pentingnya peran dan fungsi olot dalam kehidupan masyarakat adat, maka diperlukan seorang pemimpin 'olot' yang dapat melindungi dan mengayomi kehidupan masyarakatnya baik secara lahir maupun batin. Peranan dan pengaruh olot terhadap sistem pemerintahan desa cukup signifikan. Aparat pemerintah desa atau yang lebih tinggi lagi, tidak hanya berkoordinasi dengan ketua RW atau RT, melainkan juga dengan olot. Jalinan koordinasi ini tidak untuk urusan adat istiadat setempat saja, melainkan juga melebar ke urusan administrasi dán program pemerintah yang diimplementasikan ke dalam lingkungan masyarakat Kampung Urug. Dapat dikatakan bahwa "pintu masuk" Kampung Urug adalah rumah olot. Adapun "kunci pintunya" adalah olot, yang memungkinkan apakah hal baru dapat masuk dan menjadi bagian dari kehidupan masyarakat Kampung Urug. Ketua adat atau olot dianggap sebagai komunikator antara masyarakat dengan para leluhur. Oleh karena itu, secara psikologis peranan olot tersebut mendorong warga masyarakat Kampung Urug agar lebih menghormati dan menyegani profil ketua adat sebagai reminpin.

Dalam melaksanakan tata kehidupan sehari-hari, masyarakat Kampung Urug berpegang teguh pada penuturan ketua adat sebagai pemimpin informal tertinggi. Mereka tidak berani melanggar aturan yang telah ditetapkan oleh ketua adat dan pantang melakukan sesuatu tanpa sepengetahuannya. Dalam kehidupan sosial, ketua adat berperan dalam mempertahankan nilai-nilai yang dianut oleh masyarakatnya. Selain itu, ketua adat berperan sebagai mediator bagi pemerintah dalam penyampaian program-program dan pesan-pesan pembangunan, serta turut membantu perangkat desa dalam menyebarkan informasi yang perlu disampaikan kepada masyarakat Kampung Urug. Kampung Urug merupakan kampung adat karena salah satu kriterianya mengacu pada keteguhan masyarakatnya dalam 
mempertahankan adat istiadat warisan leluhurnya. Berbagai aspek kehidupan masyarakat diatur oleh ketentuan adat yang berlaku di sana. Ini artinya, ada hukum adat yang mengatur tatanan kehidupan masyarakat Kampung Urug. Berbicara mengenai hukum, berarti ada aturan dan sanksi di dalamnya. Begitu pula dengan hukum adat yang berlaku di sana, diekspresikan dalam aturan-aturan dan sanksi yang menyertainya jika terjadi pelanggaran. Sanksi tersebut biasanya berupa sanksi sosial dari ketua adat dan warga masyarakat lainnya. Di dalam hal ini, olot bertindak sebagai pemimpin adat yang bertanggung jawab menjaga amanat leluhurnya. Dia berkewajiban memelihara kelangsungan adat istiadat masyarakat Kampung Urug, termasuk menegakkan aturan-aturan adat setempat. Olot selalu berusaha mengingatkan warganya agar senantiasa berada dalam rel-rel adat Kampung Urug. Meskipun demikian, tidak ada sanksi normatif sebagai hukuman bagi pelanggar aturan adat. Kalaupun ada, itu hanya sebatas sanksi sosial dari olot dan warga masyarakat lainnya. Olot hanya bisa menegur dan menasihatinya, dan warga lainnya juga melakukan hal yang sama, atau secara lebih ekstrim lagi adalah dengan mengucilkannya dari lingkungan masyarakat. Jika dengan cara seperti itu pun tidak berhasil, segalanya akan dikembalikan kepada individunya sendiri. Pada umumnya, masyarakat masih percaya, ada sanksi yang lebih berat dari itu. Sanksi yang mungkin dipandang paling berat adalah tertimpa hal-hal yang tidak diinginkan, seperti terkena musibah atau penyakit. Kalau saja itu hanya menimpa pelanggarnya, tentu masih dianggap ringan. Bagaimana jika hal itu sampa menimpa seluruh warga masyarakat, tentu inilah sanksi yang paling berat. Artinya, orang-orang yang tidak berdosa harus ikut menanggung akibat perbuatan seseorang. Ketua adat berusaha melaksanakan hukum formal dengan sebaik-baiknya. Bila ada seseorang yang melakukan pelanggaran pidana, maka sebelumnya diselesaikan secara musyawarah berdasarkan adat, jika tidak mendapatkan solusi baru diselesaikan secara formal.

\section{DAFTAR PUSTAKA}

Andayani, Ria, dan Ria Intani. 2006.

Upacara Tradisional di Kampung Urug, Bogor: Dinas Kebudayaan dan Pariwisata Kab. Bogor.

Koentjaraningrat.1992.

Beberapa Pokok Antropolog Sosial, Cetakan ke-2, Jakarta Dian Rakyat.

.1997.

Pengantar Antropologi II, Pokok-Pokok Etnografi, Jakarta: Rineka Cipta.

1997.

Pengantar Antropologi : PokokPokok Etnografi II, Jakarta: Rineka Cipta.

Munandar, Soelaeman.1998.

Dinamika Masyarakat Transisi, Cetakan ke- 1, Yoyakarta: Pustaka Pelajar.

Rosmana, Tjetjep, et. al. 1993.

Eksistensi Lembaga Adat di Jawa Barat, Bandung: Depdikbud, BKSNT Bandung. 
Rostiati, Ani, et. al. 2000.

Kehidupan Sosial Budaya Masyarakat Kampung Urug, Bandung: Depdiknas, Ditjenbud, BKSNT, Bandung.

Soedjono Dirdjosiswono.1997.

"Peranan Pemimpin Formal dan Informal Bagi Pengembangan Kebudayaan Nasional", Makalah Seminar, Bandung: BKSNT Bandung.
.1992.

Beberapa Pokok Antropologi Sosial, Jakarta : PT. Penerbit Dian Rakyat.

Soekanto, Soejono 1990.

Sosiologi Suatu Pengantar, Jakarta: PT Raja Grafindo Persada.

Sukarna.1987.

Social Control/Kontrol

Masyarakat. Cetakan ke-1.

Jakarta: Rajawali Press. 